\title{
BEST PRACTICES IN TEACHING
}

Due to the rotating circle of economic crises, universities and especially business schools - have come under pressure to reconsider their concepts of management education. In broader terms, this critique suggests that business schools do more harm than good (Goshal, 2005) and that they ignore the human dimension of business and their responsibility towards the social and ecological environments (Navarro, 2008). Being confronted with such harsh critique is, at the same time, an opportunity for business schools to undertake a critical self-reflection and self-examination of their educational practices or - as Starkey and Tempest - have stated: "We need to consider a broader definition of the role of the business school as a force for achieving the good of business and society" (2009, p. 577).

In order to compete in the global knowledge market, universities therefore need to prioritize their teaching and student learning across the whole university towards the goal of Sustainable Corporate Responsibility. Best teaching and learning should be embedded into powerful learning environments which allow students to acquire knowledge, skills and attitudes to become long-term thinking, responsible leaders, as it has been defined in the Principles for Responsible Management Education (PRME). Two approaches to create best-practice learning environments are real-life case studies and real-life student projects which both lead to the strong-buy in of students, faculty and company partners. Powerful learning environments activate problem-based, self-directed and practice-oriented learning and foster students' critical thinking and problemsolving abilities.

The role of business schools has to be seen as a creator of challenging learning settings which allow the students to not only acquire contemporary business knowledge and skills, but to develop their personality towards responsible business leadership to shape the future direction of the 21st century.

\section{References}

Ghoshal, S. (2005). Bad management theories are destroying good management practices. Academy of Management Learning and Education, 4 (1): 75- 91.

Navarro, C. (2008). The MBA core curricula of top-ranked US business schools: a study in failure. Academy of Management Learning and Education, 7 (1): 108- 123.

Starkey, K and Tempest, S. (2009). The winter of our discontent: the design challenge for business schools. Academy of Management Learning and Education, 8 (4): 576-586.

Author

Prof. Dr. Markus Prandini Head of the Center for International Business School of Management and Law at Zurich University of Applied Sciences Stadthausstrasse 14, CH-8401 Winterthur markus.prandini@zhaw.ch 